\title{
Postrzeganie własnych kompetencji zawodowych przez studentów pedagogiki UMCS
}

\author{
Acquired professional competences in the assessment \\ of MSCU pedagogy students
}

Streszczenie. Artykuł stanowi komunikat z badań nad opiniami studentów pedagogiki UMCS na temat kompetencji zawodowych uzyskiwanych przez nich w trakcie studiów. Opinie te odnoszą się do poziomu zdobywanych podczas edukacji akademickiej wiedzy i umiejętności zawodowych oraz kompetencji społecznych. W opracowaniu zaprezentowano także poglądy badanych dotyczące znaczenia poszczególnych grup przedmiotów kształcenia, decydujących o ostatecznym kształcie przygotowania zawodowego absolwentów pedagogiki. Autor informuje także o podejmowaniu przez respondentów działań uzupełniających kompetencje zawodowe poza uczelnią oraz antycypacji takiej aktywności po zakończeniu edukacji akademickiej. Dopełnieniem raportu z badań są oceny badanych dotyczące szans na zatrudnienie w wyuczonym zawodzie.

Słowa kluczowe: kompetencje zawodowe, przygotowanie zawodowe, edukacja uniwersytecka.

Summary: The article presents research findings on MCSU pedagogy students' opinions about professional competences obtained by them during studies. These opinions referred to the level of knowledge, professional skills, and social competences. The paper shows the respondents' views on the importance of the various groups of subjects, which determine the final shape of the work preparedness of pedagogy graduates. The author also reports about the decisions made by the surveyed regarding taking up any complementary measures in order to upgrade and ameliorate their professional competences outside the university, and the anticipation of such an activity after finishing their academic education. A final component of the study is the respondents' evaluation of the employability in the learned profession.

Keywords: professional competences, professional preparation, university education. 


\section{Wprowadzenie}

Jak powszechnie wiadomo praca zawodowa człowieka decyduje o jego miejscu w strukturach społecznych, determinuje status ekonomiczny oraz możliwości zaspokojenia różnorakich potrzeb życiowych na odpowiednim poziomie. Badacze problematyki pracy ludzkiej podkreślają, że aktywność zawodowa powinna być także źródłem satysfakcji człowieka, motorem rozwoju jego kompetencji oraz innych cech osobowościowych. Udany start i przebieg kariery zawodowej wiąże się również z doświadczaniem uznania ze strony przełożonych, pracodawców oraz współpracowników. Często uznanie to przekłada się na prestiż jednostki, buduje jej autorytet w różnych kręgach społecznych (zob. Lelińska 2005, s. 114-115).

$\mathrm{Z}$ powyższych względów, niezmiernie istotną sprawą staje się poziom uzyskiwanego przygotowania zawodowego, które warunkuje udany start w życie zawodowe i dalszy jego przebieg. Jest ono podstawowym i koniecznym warunkiem kształtowania się osobowości zawodowej człowieka.

Przygotowanie zawodowe można ujmować na dwa sposoby. Dynamiczne (procesualne) podejście utożsamia je z procesem nabywania przez jednostkę cech i dyspozycji, które umożliwią jej skuteczne podjęcie aktywności zawodowej. W tym ujęciu, przygotowanie zawodowe odbywa się $\mathrm{z}$ reguły w szkołach zawodowych różnego szczebla, kwalifikacyjnych kursach zawodowych certyfikujących w sposób formalny kwalifikacje ich absolwentów, oraz rzadziej - w zakładach pracy (zob. Wiatrowski 2000, s. 43).

Przygotowanie zawodowe postrzegane jest również w sposób statyczny, czyli jako wynik przywołanego powyżej procesu. W literaturze przedmiotu różnie określa się jego strukturę. Bez wątpienia jednak, w ramach uzyskiwanego przygotowania zawodowego powinny znaleźć się wiedza i umiejętności zawodowe, które łącznie stanowią trzon kompetencji zawodowych. Niektórzy autorzy dodatkowo wymieniają też systemy motywacyjne (autogenne, jak i zewnętrzne) oraz różnorodne zestawy innych cech psychofizycznych. Waldemar Furmanek do elementów pozyskiwanego przygotowania zawodowego zalicza:

- „układy umiejętności zawodowych,

- systemy motywacji (...),

- odpowiednie systemy wiedzy dostosowane do charakteru zawodu, występujących w nim sytuacji i rodzajów aktywności,

- systemy innych cech psychicznych ważnych w procesach podejmowanej przez człowieka pracy zawodowej" (Furmanek 2000, s. 186). 
Z punktu widzenia pracodawców, przejawem osiągniętego przygotowania zawodowego osób zatrudnianych jest tzw. przydatność zawodowa, rozumiana jako sprawdzony poziom przygotowania zawodowego jednostki. Należy zauważyć, że ocena przydatności zawodowej konkretnej osoby na określonym stanowisku pracy może być różna - w zależności od wymagań stawianych przez poszczególnych pracodawców. Przydatność zawodowa bywa definiowana też jako funkcja uzyskanych kwalifikacji oraz motywacji, bądź jako wskaźnik zewnętrznej efektywności kształcenia zawodowego (zob. Furmanek 2000, s. 187).

Z perspektywy polityki oświatowej oraz potrzeb rynku pracy ważne wydają się być pytania o to, czy dzisiejszy pracownik powinien charakteryzować się jedynie znakomitą wiedzą i świetnymi umiejętnościami o charakterze stricte zawodowym (specjalistycznym), czy wiedza i umiejętności ogólne, dające człowiekowi możliwości właściwego postrzegania i interpretowania ewoluującej rzeczywistości nie powinny stanowić istotnego elementu składowego przygotowania zawodowego, czy tzw. „wyrobienie” intelektualne i szerokie horyzonty umysłowe nie powinny być traktowane jako czynniki rozwoju zawodowego współczesnych pracowników?

Kwestia wykształcenia ogólnego jako czynnika skutecznego funkcjonowania zawodowego podnoszona jest w ostatnich latach zarówno w opracowaniach naukowych, jak i z zakresu polityki edukacyjnej i społecznej. Ministerstwo Edukacji Narodowej i Sportu, w dokumencie z 2005 roku, stwierdza że „celem głównym rozwoju edukacji w Polsce jest podniesienie poziomu wykształcenia społeczeństwa, tak by wykształcenie co najmniej średnie stało się bardziej powszechne (...) w 2013 roku, przy jednoczesnym zapewnieniu wysokiej jakości kształcenia. Równocześnie konieczne jest stałe podnoszenie (...) przede wszystkim kwalifikacji zawodowych oraz ogólnych kompetencji niezbędnych do funkcjonowania we współczesnym społeczeństwie" (Strategia rozwoju... 2005, s. 26). MEN, projektując w 2010 roku zmiany w polskim szkolnictwie zawodowym zakładało, że „nowa podstawa programowa kształcenia ogólnego i podstawy programowe kształcenia w zawodach mają się wzajemnie uzupełniać w dążeniu do celu, jakim jest zapewnienie absolwentom możliwości dalszego kształcenia i funkcjonowania na rynku pracy" (Założenia projektowanych zmian... 2010, s. 26).

Krzysztof Symela zauważa, że wymagania współczesnego rynku pracy powodują konieczne zmiany w kształceniu zawodowym, determinują nowe podejście do roli, jaką w przygotowaniu nowego pracownika odgrywa kształcenie ogólne. „Powodzenie na rynku pracy nie zależy głównie od posiadania kwalifikacji ściśle zawodowych, ale także od posiadania dodat- 
kowych kompetencji (tzw. kompetencji kluczowych) i umiejętności, w tym kompetencji matematycznych, informatycznych, sprawnego posługiwania się językiem polskim i językiem obcym, rozumienia, porządkowania, oceniania wartości i znaczenia informacji oraz ich wykorzystywania w działaniu przez tworzenie informacji w języku właściwym dla danej dyscypliny, wyciągania wniosków, planowania, przewidywania skutków, w tym umiejętności rozwiązywania problemów, po oczekiwane przez pracodawców cechy osobowościowe, tj. aktywną postawę wobec otoczenia, samodzielne uczenie się i podejmowanie zadań oraz przestrzeganie reguł życia społecznego" (Symela, Ekspertyza do tematu..., s. 3).

Reasumując, wydaje się, że z punktu widzenia wartościowego przygotowania zawodowego wyróżniać należy dwie istotne jego składowe:

- wykształcenie ogólne oraz

- wykształcenie zawodowe (specjalistyczne).

Powyższe uwagi odnoszą się w jednakowym stopniu do wszystkich poziomów i rodzajów kształcenia zawodowego, w tym również - a może nawet szczególnie - do edukacji na poziomie wyższym i w wyjątkowy sposób - uniwersyteckiej.

\section{Założenia badawcze}

W prezentowanym opracowaniu pojęcie przygotowania zawodowego rozpatrywane jest przez pryzmat kompetencji zawodowych, postrzeganych subiektywnie przez studentów kończących edukację na studiach pedagogicznych w UMCS. Kompetencje zawodowe są tu rozumiane jako dyspozycje i cechy uzyskane w całościowym procesie kształcenia, posiadające walor użyteczności w przyszłej pracy zawodowej, zgodnej ze studiowanym kierunkiem i specjalnością. Ze względu na specyfikę zawodów pedagogicznych (nauczycielskich i nienauczycielskich) uznano, że - poza wiedzą i umiejętnościami zawodowymi - istotną składową ocenianego przygotowania zawodowego będą także kompetencje społeczne. Określono je jako zespół postaw, cech osobowościowych i aspiracji umożliwiających identyfikację z profesją, budujących poczucie tożsamości zawodowej oraz motywację do pracy w zawodzie. Taka koncepcja uzyskiwanego przygotowania zawodowego odzwierciedla również strukturę efektów kształcenia, które stanowią filar Krajowych Ram Kwalifikacji.

Referowane badania przeprowadzono w kwietniu 2013 roku, w Instytucie Pedagogiki UMCS w Lublinie, na losowej próbie 91 osób, studiujących 
stacjonarnie i niestacjonarnie różne specjalności na kierunku pedagogika. Wszyscy respondenci byli absolwentami studiów licencjackich w Instytucie Pedagogiki UMCS, a w momencie badań kończyli studia uzupełniające magisterskie. Było to najistotniejsze założenie badań, gdyż chodziło w nich o oceny uzyskanego przygotowania zawodowego ze strony osób mogących udzielić na ten temat najbardziej wiarygodnych i rzetelnych informacji (po pełnym 5-letnim cyklu studiów).

Badania miały charakter sondażowy; prowadzono je korzystając z obecności studentów na zajęciach dydaktycznych. Narzędzie w swej merytorycznej części składało się w większości z pytań opartych na dyferencjale semantycznym, ale zawierało także pytania otwarte i półotwarte.

Przedmiotowy zakres badań można podzielić na 4 zasadnicze obszary problemowych:

1. Ocena poziomu:

a) wiedzy zawodowej,

b) umiejętności zawodowych i

c) kompetencji społecznych,

zdobytych podczas studiów w UMCS wraz ze wskazaniem podstaw dla wartościowania tych elementów przygotowania zawodowego.

2. Ocena przydatności przygotowania zawodowego, uzyskiwanego na:

a) przedmiotach kształcenia ogólnego,

b) przedmiotach kierunkowych/specjalnościowych o charakterze teoretycznym,

c) przedmiotach kierunkowych/specjalnościowych o charakterze praktycznym,

d) praktykach zawodowych.

3. Uzupełnianie i antycypacja uzupełnienia uzyskanego na studiach przygotowania zawodowego w innych formach edukacyjnych.

4. Perspektywy dotyczące szans na zatrudnienie po ukończeniu studiów.

\section{Ocena poziomu kompetencji zawodowych}

Ogólna ocena wystawiona przez respondentów uzyskiwanemu podczas studiów przygotowaniu zawodowemu nie była zbyt wysoka, choć badani wartościujący je ponadprzeciętnie stanowili znaczną część próby (41,76\%). Najliczniej (1/2 badanych) reprezentowani byli ci, którzy nadawali mu środkową notę oceniającą ocenną. Warto też zauważyć, że nikt spośród respondentów nie określił swego przygotowania zawodowego jako bardzo słabego. 
Tab. 1. Ocena całościowa osiągniętego podczas studiów poziomu przygotowania zawodowego

\begin{tabular}{|c|c|c|c|c|c|}
\hline \multirow{2}{*}{} & \multicolumn{5}{|c|}{ Wartości ocen na skali dyferencjatu } \\
\cline { 2 - 6 } & $\begin{array}{c}1 \\
\text { bardzo niski }\end{array}$ & $\begin{array}{c}2 \\
\text { niski }\end{array}$ & $\begin{array}{c}3 \\
\text { przeciętny }\end{array}$ & $\begin{array}{c}4 \\
\text { wysoki }\end{array}$ & $\begin{array}{c}5 \\
\text { bardzo wysoki }\end{array}$ \\
\hline $\mathrm{N}$ & 0 & 8 & 45 & 34 & 4 \\
\hline$\%$ & 0 & 8,79 & 49,45 & 37,36 & 4,4 \\
\hline
\end{tabular}

Źródło: badania własne

Średnia arytmetyczna ocen całościowo ujętego przygotowania zawodowego (liczona dla wartości od 1 do 5) wyniosła 3,37.

Lepsze zdanie na temat przygotowania zawodowego jakie dała im uczelnia mieli badani studiujący w trybie niestacjonarnym. Średnia ich ocen była wyższa o ponad pół punktu od średniej ocen studentów stacjonarnych.

Rys. 1. Średnia ocen poziomu uzyskanego przygotowania zawodowego a tryb studiów

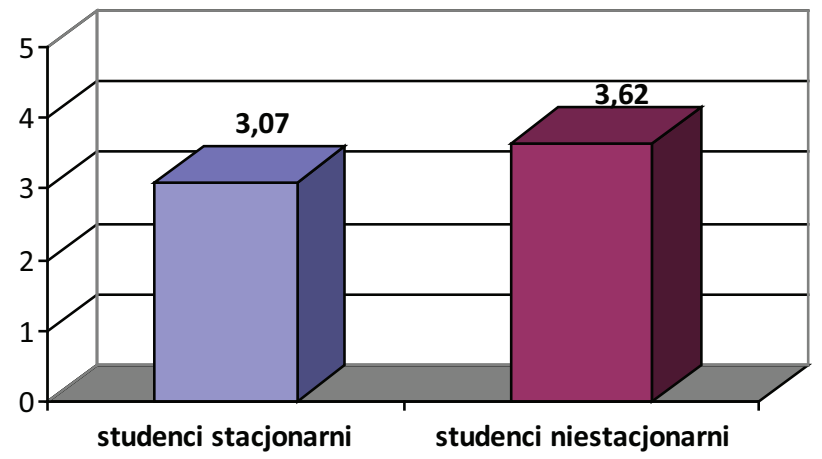

Żródło: badania własne

Respondenci w różny sposób oceniali poszczególne elementy składowe swojego przygotowania zawodowego. Względnie wysoko wartościowali wiedzę zawodową (zarówno teoretyczną i praktyczną). Niemal 60\% spośród nich uznało, że prezentuje ona poziom wysoki i bardzo wysoki, a zaledwie co dziesiąty badany stwierdził, że dysponuje słabym i bardzo słabym poziomem wiadomości z zakresu studiowanej profesji. Badani studenci najliczniej określali poziom swojej wiedzy zawodowej jako wysoki. 
Tab. 2. Ocena poziomu uzyskanej podczas studiów wiedzy zawodowej

\begin{tabular}{|c|c|c|c|c|c|}
\hline \multirow{2}{*}{} & \multicolumn{5}{|c|}{ Wartości ocen na skali dyferencjału } \\
\cline { 2 - 6 } & $\begin{array}{c}1 \\
\text { bardzo niski }\end{array}$ & $\begin{array}{c}2 \\
\text { niski }\end{array}$ & $\begin{array}{c}3 \\
\text { przeciętny }\end{array}$ & $\begin{array}{c}4 \\
\text { wysoki }\end{array}$ & $\begin{array}{c}5 \\
\text { bardzo wysoki }\end{array}$ \\
\hline $\mathrm{N}$ & 1 & 9 & 27 & 52 & 2 \\
\hline$\%$ & 1,1 & 9,89 & 29,67 & 57,14 & 2,2 \\
\hline
\end{tabular}

Żródło: badania własne

Takie deklaracje przełożyły się na wyższą średnią ocen wiedzy zawodowej $(3,49)$ od średniej ocen całościowo ujętego przygotowania zawodowego $(3,37)$.

Spośród trzech wyróżnionych w przygotowaniu zawodowym komponentów, najsłabiej oceniano zdobyte podczas studiów umiejętności zawodowe, czyli ukształtowaną możność i gotowość do wykorzystania posiadanej wiedzy zawodowej w sytuacjach praktycznego wykonywania zawodu.

Ponad 1/4 badanych określiła swe umiejętności zawodowe jako słabe i bardzo słabe, zaś niewiele ponad $1 / 3$ była przeciwnego zdania (dobre i bardzo dobre oceny). Pozostali $(36,26 \%)$ stwierdzili, iż ich dyspozycje do praktycznego wykorzystania posiadanej wiedzy w trakcie wykonywania przyszłych zadań zawodowych są co najwyżej przeciętne.

Tab. 3. Ocena poziomu uzyskanych podczas studiów umiejętności zawodowych

\begin{tabular}{|c|c|c|c|c|c|}
\hline & \multicolumn{5}{|c|}{ Wartości ocen na skali dyferencjału } \\
\cline { 2 - 6 } & $\begin{array}{c}1 \\
\text { bardzo niski }\end{array}$ & $\begin{array}{c}2 \\
\text { niski }\end{array}$ & $\begin{array}{c}3 \\
\text { przeciętny }\end{array}$ & $\begin{array}{c}4 \\
\text { wysoki }\end{array}$ & $\begin{array}{c}5 \\
\text { bardzo wysoki }\end{array}$ \\
\hline $\mathrm{N}$ & 3 & 21 & 33 & 30 & 4 \\
\hline$\%$ & 3,3 & 23,08 & 36,26 & 32,97 & 4,4 \\
\hline
\end{tabular}

Żródło: badania własne

Poziom umiejętności zawodowych uzyskał średnią ocen badanych niewiele przewyższającą wartość przeciętną na pięciopunktowej skali dyferencjału semantycznego $(3,12)$. Świadczy to z pewnością o dość małej satysfakcji respondentów z efektów kształcenia w zakresie przygotowania do praktycznego wykonywania ich przyszłych zadań i czynności zawodowych. 
Zdecydowanie najlepiej respondenci postrzegali ukształtowane podczas edukacji akademickiej, niezbędne do skutecznej pracy w wyuczonym zawodzie kompetencje społeczne. Zaledwie co trzynasty badany wyraził swe wyraźne niezadowolenie $\mathrm{z}$ tego aspektu przygotowania zawodowego, podczas gdy niemal $60 \%$ respondentów było dość lub bardzo zadowolonych $\mathrm{z}$ ukształtowanych w nich podczas studiów kompetencji społecznych. Należy jednak dodać, że 1/3 wszystkich uczestników badań uznała owe kompetencje za jedynie przeciętne.

Tab. 4. Ocena poziomu uzyskanych podczas studiów kompetencji społecznych

\begin{tabular}{|c|c|c|c|c|c|}
\hline \multirow{2}{*}{} & \multicolumn{5}{|c|}{ Wartości ocen na skali dyferencjału } \\
\cline { 2 - 6 } & $\begin{array}{c}1 \\
\text { bardzo niski }\end{array}$ & $\begin{array}{c}2 \\
\text { niski }\end{array}$ & $\begin{array}{c}3 \\
\text { przeciętny }\end{array}$ & $\begin{array}{c}4 \\
\text { mysoki }\end{array}$ & $\begin{array}{c}5 \\
\text { bardzo wysoki }\end{array}$ \\
\hline $\mathrm{N}$ & 1 & 6 & 30 & 36 & 18 \\
\hline$\%$ & 1,1 & 6,59 & 32,97 & 39,56 & 19,78 \\
\hline
\end{tabular}

Źródło: badania własne

Rys. 2. Średnie ocen poziomu zdobytych na studiach wiedzy, umiejętności i kompetencji społecznych a tryb studiów respondentów

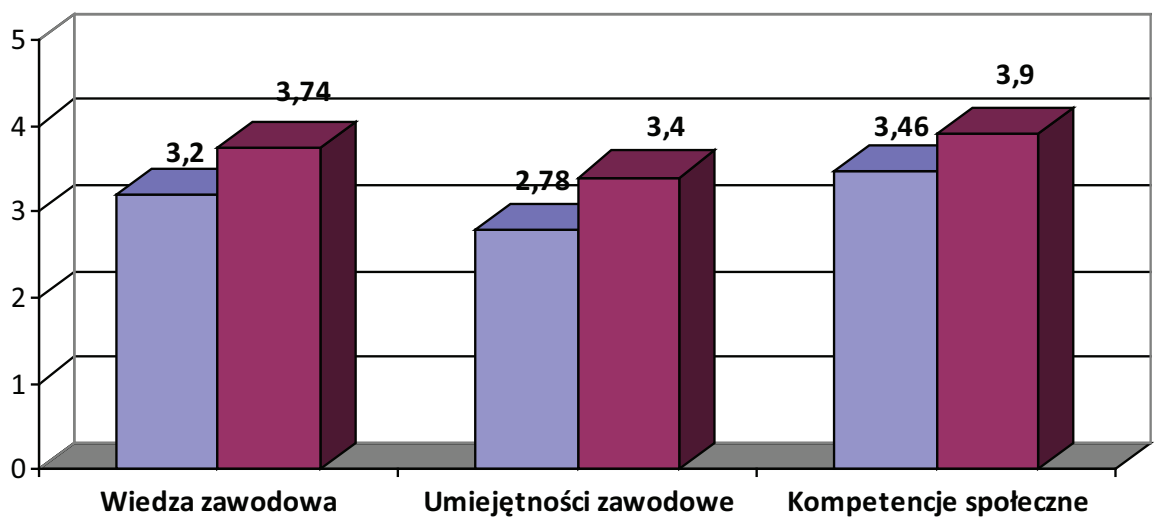

$\square$ studenci stacjonarni

$\square$ studenci niestacjonarni

Źródło: badania własne 
$\mathrm{Na}$ tle ocen wystawianych przez respondentów poziomowi uzyskanej wiedzy, jak i umiejętności zawodowych, średnia arytmetyczna not wartościujących kompetencje społeczne okazała się względnie wysoka $(3,7)$ i znacząco zbliżyła się do oceny wysokiej.

Tryb studiów badanych był czynnikiem różnicującym oceny trzech składowych przygotowania zawodowego.

Studenci stacjonarni byli bardziej krytycznie nastawieni do wszystkich trzech wyróżnionych komponentów przygotowania zawodowego uzyskiwanego podczas studiów. Badani kształcący się w trybie niestacjonarnym wysoko cenili sobie zdobyte kompetencje społeczne (3,9 na skali 1-5), nieco mniej optymistycznie postrzegali posiadaną wiedzę zawodową $(3,74)$. Najniżej wartościowali ukształtowane na studiach umiejętności zawodowe $(3,4)$, choć w tym przypadku rozbieżność ocen studiujących dziennie i zaocznie była największa.

Rys. 3. Podstawy ocen całościowo ujętego przygotowania zawodowego uzyskanego podczas studiów

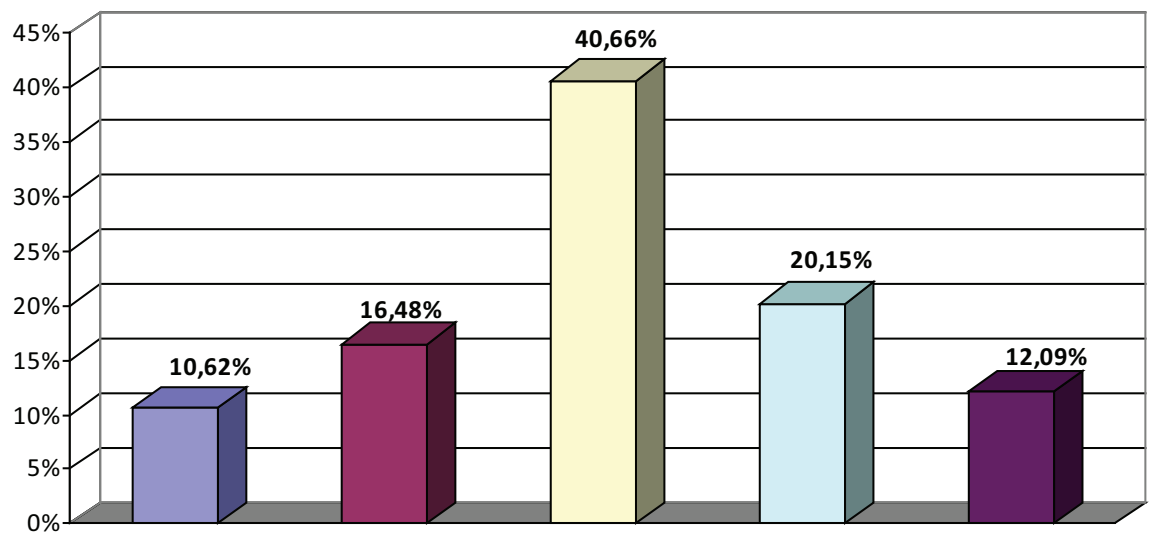

$\square$ Uzyskiwane wyniki w nauce

$\square$ Porównanie poziomu własnej wiedzy, umiejętności i kompetencji z ich poziomem u innych studentów

$\square$ Doświadczenia wyniesione z praktyk studenckich

$\square$ Doświadczenia z pracy w zawodzie lub zawodach pokrewnych

$\square$ Opinie osób znajomych pracujących w zawodzie

Źródło: badania własne 
Uzupełnieniem, a w pewnym stopniu również próbą wyjaśnienia dość przeciętnego poziomu zadowolenia badanych $\mathrm{z}$ uzyskanego podczas studiów przygotowania zawodowego mogą być informacje na temat podstaw wystawiania ocen poziomu wiedzy, umiejętności oraz kompetencji społecznych. Badani, w zdecydowanej większości wykazali się praktycystycznym podejściem do tej kwestii.

Dla ponad 60\% spośród respondentów najważniejszym kryterium wartościowania własnego przygotowania zawodowego było jego sprawdzenie w praktycznym działaniu - albo podczas praktyk studenckich, albo w trakcie podejmowanej pracy zawodowej. Rzadziej odwoływali się do porównywania własnego przygotowania z przygotowaniem innych studentów. Dla najmniej licznych, miarodajną podstawą do omawianych ocen były opinie znajomych pracujących w zawodach wymagających przygotowania pedagogicznego oraz poziom uzyskiwanych wyników w nauce. Można skonstatować, że dla większości respondentów, zasadniczym kryterium oceny skuteczności procesu przygotowania zawodowego na studiach był poziom sprawności działania w warunkach rzeczywistej pracy zawodowej lub w zbliżonych do nich.

Szczególne docenianie przez respondentów praktycznej strony przygotowania zawodowego odzwierciedlają także ich preferencje dotyczące struktury przedmiotów kształcenia uniwersyteckiego na kierunkach pedagogicznych.

Rys. 4. Preferowany udział różnych grup przedmiotów w kształceniu uniwersyteckim

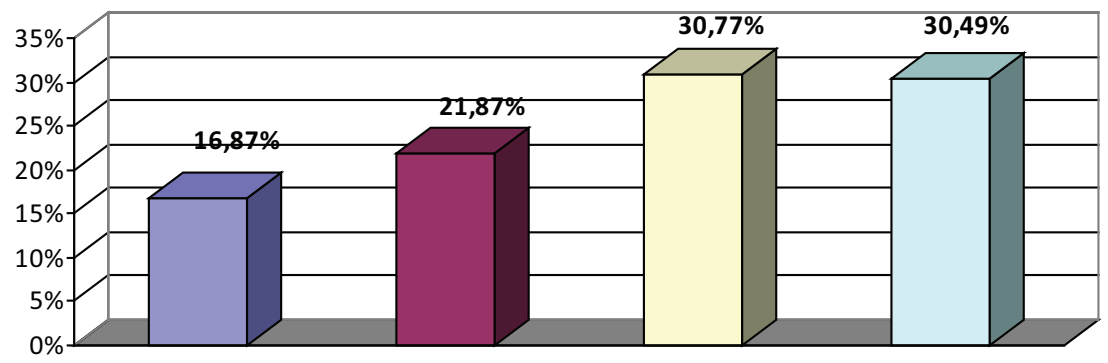
$\square$ Przedmioty kształcenia ogólnego
$\square$ Przedmioty kierunkowe/specjalnościowe teoretyczne
$\square$ Przedmioty kierunkowe/specjalnościowe praktyczne
$\square$ Praktyki studenckie

Źródło: badania własne 
Zdaniem badanych, w ramach edukacji uniwersyteckiej przedmioty kierunkowe i specjalnościowe o charakterze praktycznym, a także praktyki studenckie powinny stanowić łącznie aż 60\% całej puli studiowanych przedmiotów. Za najmniej istotne w akademickim kształceniu uznane zostały przedmioty kształcenia ogólnego, tj. takie, które w największym stopniu warunkują poziom kultury umysłowej, erudycję oraz ogólną orientację we współczesnym świecie. Wypada zatem stwierdzić, iż preferowana przez badanych struktura i charakter obszarów kształcenia na studiach różni się od obecnie istniejącej oraz odzwierciedla zdecydowanie praktyczno-zawodowe oczekiwania respondentów wobec edukacji uniwersyteckiej.

Wobec powyższych spostrzeżeń, nie dziwi sposób, w jaki badani oceniali przydatność poszczególnych grup przedmiotów dla uzyskiwanego przygotowania zawodowego. W skali od 1 do 5 , najwyżej ceniono w omawianym kontekście praktyki studenckie $(4,2)$. Na niższym poziomie wartościowano przedmioty kierunkowe (specjalnościowe), zarówno praktyczne, jak i teoretyczne (średnia odpowiednio: 3,8 i 3,6). Najmniej przydatne dla przygotowania zawodowego były zdaniem badanych przedmioty kształcenia ogólnego $(2,6)$.

Wskazany wcześniej niezbyt wysoki poziom zadowolenia badanych z uzyskanego podczas studiów przygotowania zawodowego, powinien skłaniać ich do poszukiwania dodatkowych sposobów uzupełniania wiedzy, umiejętności i innych istotnych dla pracy zawodowej kompetencji.

\section{Rys. 5. Uzupełnianie przygotowania zawodowego w formach (ofertach) pozaakademickich}

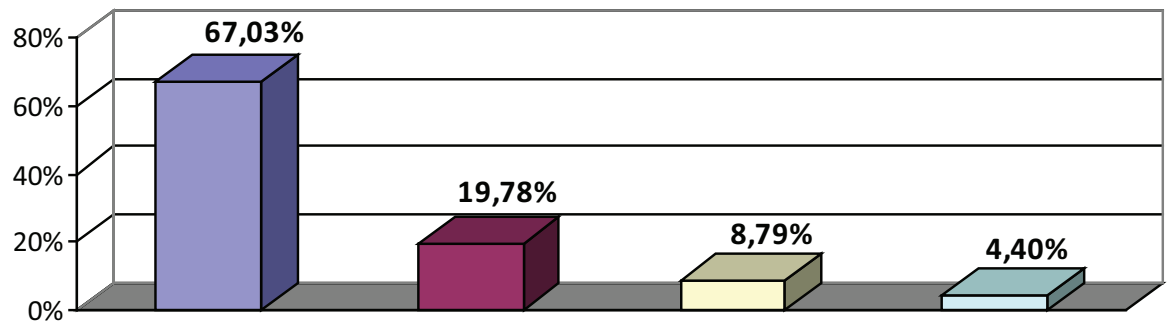

$\square$ brak uzupełniania przygotowania zawodowego

$\square$ szkolenia i kursy

$\square$ staże zawodowe, praktyki

$\square$ wolontariat 
Wbrew oczekiwaniom, respondenci rzadko korzystali z pozaakademickich form umożliwiających uzupełnienie lub modernizację przygotowania zawodowego (1/3 próby). Najczęściej kończyli różnego rodzaju szkolenia i kursy (prawie 20\%), zdecydowanie rzadziej realizowali staże zawodowe lub samodzielnie organizowane praktyki. Zaledwie $4,4 \%$ z nich uczestniczyło w trakcie studiów w działaniach woluntarystycznych.

Ponad połowa badanych zadeklarowała jednak potrzebę, a nawet konieczność uzupełnienia przygotowania zawodowego po zakończeniu edukacji akademickiej. Znaczna ich część nie motywowała takich zamiarów zbyt słabym przygotowaniem uzyskanym podczas studiów, lecz obiektywną potrzebą nadążania za zmianami zachodzącymi w teorii i praktyce pedagogicznej. Warto nadmienić, że ponad $1 / 3$ respondentów nie wiedziała czy podejmie się uzupełniania swych kompetencji zawodowych po zakończeniu studiów.

Rys. 6. Przewidywanie konieczności uzupełniania przygotowania zawodowego po ukończeniu studiów

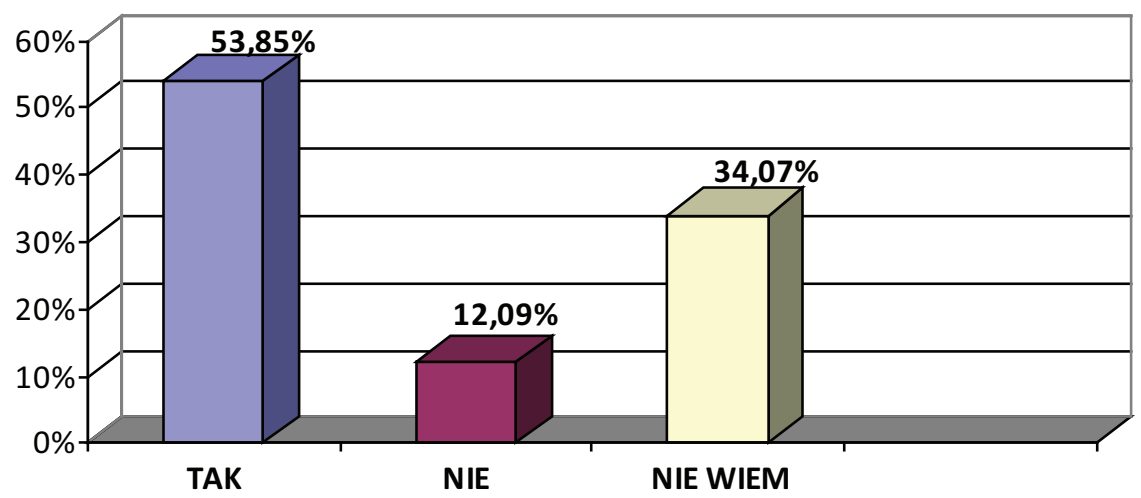

Źródło: badania własne

Uczestnicy badań realistycznie postrzegali swe szanse na znalezienie zatrudnienia po ukończeniu studiów. Połowa z nich oceniła je jako przeciętne, 1/3 jako małe, a jedynie 3,3\% - jako duże. Pozostali badani w momencie badań posiadali już zatrudnienie. W uzupełnieniu tych informacji należy dodać, że pesymistyczne oceny możliwości uzyskania zatrudnienia wynikały ze znajomości sytuacji na rynku pracy oraz trwania niżu demograficznego, powodującego likwidację części etatów w placówkach edukacyjnych. 


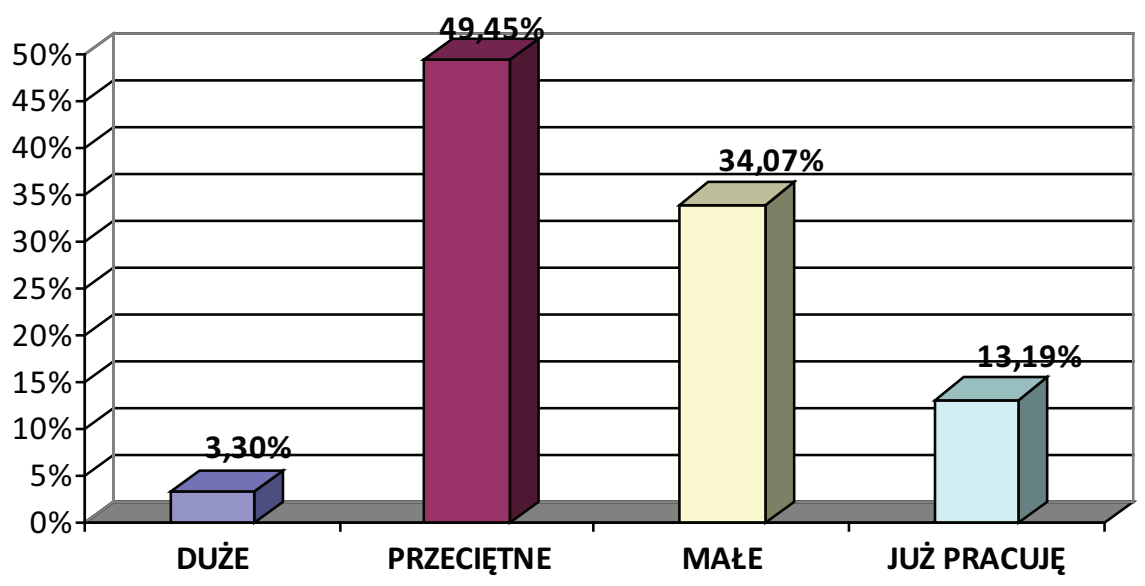

Źródło: badania własne

\section{Podsumowanie}

Jak pokazały zaprezentowane w skrócie wyniki badań, studenci pedagogiki w UMCS oceniali poziom uzyskanego tam przygotowania zawodowego jako nieco wyższy niż przeciętny. Względnie najwyżej wartościowali poziom kompetencji społecznych oraz wiedzę ogólną i specjalistyczną. Najmniej zadowoleni byli z wyposażenia w odpowiednie umiejętności zawodowe. Swoje opinie opierali głównie na doświadczeniach płynących z konfrontacji posiadanego przygotowania z zadaniami zawodowymi, przydzielanymi im podczas praktyk studenckich lub podejmowanego zatrudnienia.

Stosunkowo dobra ocena poziomu zdobywanej podczas studiów wiedzy nie korespondowała $w$ deklaracjach badanych z oceną jej przydatności dla przygotowania zawodowego. Najważniejszą rolę w tym aspekcie - zdaniem respondentów - pełnią praktyczne przedmioty kierunkowe oraz praktyki w placówkach edukacyjnych. Co więcej, uczestnicy badań uznali te właśnie obszary kształcenia za najistotniejsze dla edukacji uniwersyteckiej. Tym samym, badani preferowali odejście od klasycznego modelu kształcenia na uniwersytetach, mocno akcentującego potrzebę wszechstronnego kształtowania umysłu, na rzecz priorytetu utylitarnego kształcenia zawodowego.

Mimo że znaczna część badanych nie była w pełni usatysfakcjonowana uzyskanym przygotowaniem zawodowym, to zaledwie co trzeci z nich po- 
dejmował w trakcie studiów próby uzupełnienia lub podwyższenia swych kompetencji. Należy jednak przypomnieć, że ponad połowa respondentów zadeklarowała takie działania po zakończeniu studiów. Część badanych nie planowała podjęcia w przyszłości dokształcania lub doskonalenia zawodowego ze względu na niepewność co do możliwości uzyskania zatrudnienia w wyuczonym zawodzie.

Niezależnie od stopnia trafności zaprezentowanej diagnozy, oceny uzyskanego przez studentów przygotowania zawodowego skłaniają do postawienia następujących pytań:

- Czy zjawisko niepełnego zadowolenia z kompetencji zawodowych pozyskiwanych podczas studiów jest obecne w innych ośrodkach akademickich kraju (w tym na innych wydziałach i kierunkach)?

- Dlaczego studenci nie doceniają roli, jaką powinny pełnić w ich przygotowaniu zawodowym poszczególne komponenty kształcenia - w szczególności przedmioty kształcenia ogólnego?

- Na ile edukacja uniwersytecka - z punktu widzenia wymagań współczesnego rynku pracy - powinna służyć praktycznemu przygotowaniu zawodowemu absolwentów, a na ile dbać o etos wszechstronnego, możliwie pełnego wykształcenia (universitas)?

- Czy i w jakim zakresie prace nad wdrażaniem Krajowych Ram Kwalifikacyjnych powinny uwzględniać sugestie płynące z krytycznych opinii studentów wobec przydatności poszczególnych grup przedmiotów w ich przygotowaniu zawodowym?

Mimo wątpliwości dotyczących zasadności sugerowanych przez badanych niedostatków w uzyskiwanych podczas studiów kompetencjach zawodowych, z pewnością nie wolno tych sygnałów lekceważyć, lecz poddać wnikliwej weryfikacji.

\section{Bibliografia}

Furmanek W. (2000), Podstawy edukacji zawodowej, Rzeszów.

Lelińska K. (2005), Znaczenie socjologicznych teorii wyboru zawodu w pracy doradcy zawodowego, [w:] Bednarczyk H., Figurski J., Żurek M. (red.), Pedagogika Pracy-doradztwo zawodowe, Warszawa-Radom.

Strategia rozwoju edukacji na lata 2007-2013. Ministerstwo Edukacji Narodowej i Sportu (2005).

Wiatrowski Z. (2000), Podstawy pedagogiki pracy, Bydgoszcz. 


\section{Netografia}

Założenia projektowanych zmian. Kształcenie zawodowe i ustawiczne (2010), s. 26, dostępny na: http://www.men.gov.pl/images/pdf/4.pdf (otwarty: 04.05.2013).

Symela K., Ekspertyza do tematu projektu innowacyjnego Nr 21 - Modernizacja oferty kształcenia zawodowego w powiązaniu z potrzebami lokalnego i regionalnego rynku pracy, dostępny na: http://www.lodzkie.pl/wps/wcm/connect/lodzkie/lodzkie/kontakt/wynik.html?cx=000911057048140126527\% 3A8pwrr4bchgs\&cof=FORID\%3A11\&ie=UTF-8\&q=Symela\&sa=+\&siteurl= (otwarty 04.05.2013). 